\title{
Links between State, School and Businesses in Training Community Ecotourism at Tuyen Quang Province (Vietnam): Situation and Solutions
}

\author{
Le Ngoc Thong* \\ National Economics University, Hanoi, Vietnam
}

*Corresponding Author: Le Ngoc Thong, National Economics University, Hanoi, Vietnam

\begin{abstract}
With appropriate and specific scientific research methods, the article is through the content towards the realization of the goal: contribute to perfecting the theory of the unity between the four subjects (state vocational school, home people and businesses) in community ecotourism vocational training; research on the situation and results of the above consensus. Since then, proposing some effective solutions to improve the efficiency of community eco-tourism vocational training in Tuyen Quang province.
\end{abstract}

Keywords: vocational training; travel; training links; Tuyen Quang province.

\section{INTRODUCTION}

The current trend is that tourism development must become a spearhead economic sector on the basis of efficiently exploiting advantages of natural conditions, ecology, historical cultural traditions,mobilize to the utmost all resources, contributing to the industrialization and modernization of the country. Having made great contributions in the history of the nation, today, Tuyen Quang province has great tourism potential because of its beautiful natural landscape, colorful culture and honest people.In recent years, tourism in Tuyen Quang province has prospered and achieved many achievements. But the workforce of the tourism industry has not fully met the community ecotourism requirements in terms of structure, quality and quantity. Therefore, strengthening the community ecotourism vocational training in this charming land is an urgent issue. One of the solutions is to effectively implement the linkage between the state - vocational institutions, local people and businesses in community ecotourism vocational training in Tuyen Quang province.

\section{OVERVIEW, OBJECTIVES AND RESEARCH METHODS}

\subsection{Overview of Research}

According to the orientation of resolution 08 - NQ / TW, Vietnam's tourism development is also mentioned in many seminars and scientific research projects.

Assoc. Doctor. Le Anh Tuan (2016), "Link to develop Northwestern tourism human resources", published in the Tourism Journal, has focused on exploiting the current situation of the quality of Northwest tourism from the contingent of state management officials, the workforce in tourism businesses to the local tourism human resource. Since then, proposing solutions to link labor development in tourism activities in the Northwest Nguyen Son Ha (2016), "Training of human resources for tourism today", Journal of Culture and Arts No. 382. The article mentions the status of both the quality and the number of employees in the tourism industry in Vietnam. The author has proposed 4 groups of solutions to train human resources according to social needs and international integration trends.

Duong Van Sau, (2012) "Human resource training for Vietnam tourism - Theoretical and practical issues" - Scientific conference proceedings. This proceedings has brought a lot of information about the theory, status and solutions for tourism human resource training

Through an overview of some researches, it shows:

(1) Very few works on linkages between actors in tourism vocational training and community ecotourism. 
(2) Solving the problem of tourism manpower, Vietnam will fully afford and meet the conditions to promote community ecotourism development.

\subsection{Research Objectives and Methods}

2.2.1. Article objectives towards:

(1) Contributing to perfecting the theory of unity among actors (state - people's vocational schools and businesses) in community ecotourism vocational training;

(2) Research on the current status and results of agreement among actors in community ecotourism vocational training.

(3) Proposing solutions to improve the efficiency of community ecotourism vocational training in Tuyen Quang province.

\subsubsection{Research Methods}

(1) Reaching the above target, the article uses a combination of suitable scientific research methods, in particular quantitative and qualitative; fact studies, literature studies, ...

(2) How to collect data: secondary data through documents such as books, newspapers, reports, magazines, ... Partly collecting primary data through interviews and sociological surveys

Data processing: Using methods of analysis, comparison, synthesis. The statistics are used in comparing, analyzing, interpreting and inferring, synthesizing necessary judgment.

\section{RESEARCH RESULTS}

\subsection{Theories About Community Ecotourism Vocational Training}

\subsubsection{The Concept of Community Ecotourism}

According to Nicole Hausle and Wollfgang Strasdas (2009): "Community ecotourism is a form of tourism in which local people develop and manage it.The economic benefits gained from tourism will be stagnant in the local economy".

Respondsible Ecological Social Tours (1997) said that community ecotourism is "a way of organizing tourism that emphasizes the environment, culture and society.Community ecotourismis owned and managed by the community, for the community and allows tourists to raise awareness and learn about the community and their daily lives.".

In summary (according to vi.wikipedia.org), ecotourism is a type of tourism organized by the community, based on the local nature and culture with the aim of protecting the environment. There, promoting ownership, paying attention to widely distributing benefits and improving the quality of life for the community.For tourists, community ecotourism creates opportunities to learn about and raise awareness about the environment and cultural exchanges, and experience daily life of the community. That is the essence of ecotourism and sustainable tourism. In particular, emphasis on all three factors: environment, tourism and community.

\subsubsection{Theories About Community Ecotourism Vocational Training}

\subsubsection{The concept of vocational training association}

It is the cooperation between the entities (parties) participating in organizing the implementation of programs agreed in vocational training on vocational training subjects, purposes and contents. Community ecotourism vocational training trains workers working in the community ecotourism industry to understand and exercise necessary professional capacity. That is an objective need, derived from the interests of the parties. Develop a mechanism for close linkage between state management agencies (a) with vocational training institutions (b) and local people (c), community ecotourism businesses (d) . 
3.1.2.2. Content of the link between 4 subjects in community ecotourism vocational training in community ecotourism vocational training, 4 subjects have a close relationship, as shown in the following figure:

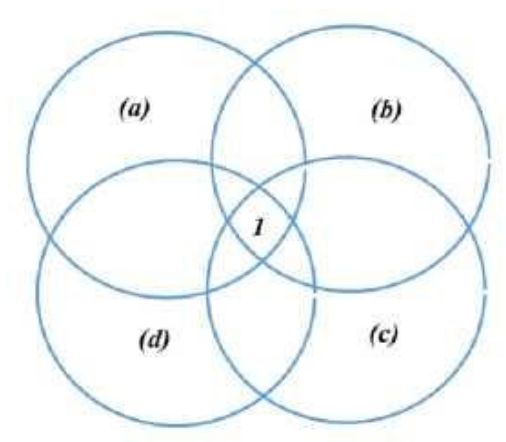

In which:

1. Community ecotourism workers

a. State management agencies

b. Vocational training institutions

c. Local people

d. Community ecotourism business

Figure1. Relationship between 4 subjects in community ecotourism vocational training

(Source: self-built by author)

This is a deep relationship, interwoven with many levels.

(1)The central layer: the overall correlation between the four subjects for the general purpose of vocational training (see below). This correlation determines the existence of association in vocational training. To do that requires the participation of four agencies: State (human resource development orientation, state management first of all at the provincial level and the tourism industry); schools (training institutions), houses and entrepreneurs (operating in the tourism sector).

The central layer is only made and shown through other layers of relations (bilateral relations).

(2) The relationship between the school and the state management agency on employees is done through mechanisms and policies in accordance with the law. The school receives additional training and training information through this organization, and at the same time, provides trained human resources to businesses.

(3) The relationship between state management agencies on employees and businesses is also done through mechanisms and policies in accordance with the law. Businesses that supply recruitment needs and requirements to state management agencies and, at the same time, are allowed to recruit through this organization. State management agencies develop a mechanism to bind businesses to pay fees when recruiting workers without participating in training.

(4) The relationship between the school and business is done through comprehensive cooperation agreements. Thereby, the business provides recruitment needs and requirements, participates in the process of building training programs, is in charge of training for advanced vocational skills for learners.

(5) House-to-business relations for mutual and complementary impacts in tourism activities and technical guidance of tourism

Therefore, in vocational training should the overall implementation of all 4 above correlations:

$$
(1)=(2)+(3)+(4)+(5)
$$

The Japanese model of local vocational association is an illustration. Accordingly, the school has a good role in educating learners about ethics, labor discipline, industrial style, and vocational capacity training at a basic level. Businesses are responsible for providing additional training to learners on their own intensive working capacity, suitable to their own production needs. The training of human resources has the participation of many parties: the school (manpower supply), the people's house both supply and demand for labor; business (human resource needs), functional agencies act as a bridge (human bank management and supplementary education). In which:

- Training institutions register resource information with the bridge authorities to be provided with 
information on human resource needs and business cooperation needs.

- The businesses registers the needs and conditions of recruitment of employees for the bridge authorities to be introduced to appropriate human resources.

- Bridge authorities include human bank data management agencies and supplementary education agencies. This agency is responsible for receiving human resource needs from businesses to supply to training institutions, at the same time, introducing trained human resources and additional training to businesses..

Thus, through this linkage, the school's training always meets the needs of the business. At the same time, the businesses always receives employees in accordance with the needs and production characteristics. However, businesses are obliged to pay fees to the bridge authorities to store information on human resource needs and additional training..

\subsubsection{The Objective of the Vocational Vieclien Ecotourism Community:}

(1) Promoting the inherent strengths of all 4 subjects; improve the strength and role of each subject in the association; become a counterbalance, orientation for other subjects.

(2) The main goal of the linkage is to step by step develop a training model according to the demand and order of the community ecotourism, training workers in the field of management and expertise.

(3) Towards meeting the labor needs of Businesses,contribute to the development of human resources in the tourism industry with professional capabilities in the community ecotourism field; promoting the strengths of the locality, meeting the needs of tourists and the locality and the country.

(4) Developing professional capacity for the workforce in the community ecotourism profession

Competency is a combination of attributes of an individual person, including knowledge, skills, and attitudes, in accordance with the requirements of a certain activity (task, job), make sure it works."Competencies are made up of the basic parts: 1)Knowledge of certain areas of activity or relationship; 2) Skills to conduct activities or promote, deal with (in) a certain relationship; 3) Psychological conditions for organizing and implementing that knowledge and skills in a unified structure and in a clear direction, such as will - motivation, emotion - attitude towards the task, or generally intellectual, communicative, learning, .. (see figure 2) [2; 20-21]

Occupational capacity is the sum of human psychological and physiological characteristics that meet the requirements of the profession. Professional capacity is formed and developed through educational, learning and labor activities.

Professional capacity in community ecotourism (see figure 3) [3;162]:

\begin{tabular}{|l|l|}
\hline In which: \\
1. Knowledge \\
2. Skill \\
3. Attitude, behavior \\
4. Competence
\end{tabular}

Figure2. Competency Model

[Source: self-built by author]

According to VTOS, capacities include 241comnetencv unit:21 General competency unit; 167Specialized competency unit; 30 Management competency unit; 13 Responsible tourism competency unit; 10 Basic competency unit.

This is specifically implemented by the Competency Framework for Tourism Professionals (according to the ASEAN Common Standards - ACCSTP - see Figure 5) [3; 163]: Then, capacity including: Core competencies; Functional and technical competency; General competency 
Tourism Professional Competency Framework is legalized by the Vietnam National Qualifications Framework - VQF (promulgated by the Government in October 2016). Through theoretical research and practical documents, along with legal documents on tourism development orientation, the author proposes a professional capacity framework with 28 criteria to promote the local ecological potentials.

Table1. Criteria in the Tourism Professional Competency Framework

\begin{tabular}{|c|c|c|c|}
\hline Group & Quantity & Content & \\
\hline Knowledge & 06 & $\begin{array}{l}\text { 1. Professional skills } \\
\text { 2. History, culture, geography } \\
\text { 3. Common fields }\end{array}$ & $\begin{array}{l}\text { 4. Economy, politics, law } \\
5 \text {. Tourist products in tourist spots } \\
\text { 6. Tourist site is working }\end{array}$ \\
\hline Skills & 11 & $\begin{array}{l}\text { 7. Profession } \\
\text { 8. Communication } \\
\text { 9. Foreign language communication } \\
\text { 10. Solve the problem } \\
\text { 11. Independent work } \\
\text { 12. Team work }\end{array}$ & $\begin{array}{l}\text { 13. Observe in work } \\
\text { 14. Explanation and persuasion } \\
\text { 15. Drafting documents } \\
\text { 16. Organization and management } \\
\text { 17. Creative innovation }\end{array}$ \\
\hline Attitude & 11 & $\begin{array}{l}\text { 18. Passionate, enthusiastic } \\
\text { 19. Professionalism, seriously } \\
\text { 20. Withstand high pressure } \\
\text { 21. Be patient, learn, improve } \\
\text { 22. Dynamic, flexible } \\
\text { 23. Cheerful, polite }\end{array}$ & $\begin{array}{l}\text { 24. A sense of responsibility } \\
\text { 25. Compliance with regulations } \\
\text { 26. Cooperation with colleagues } \\
\text { 27. Interested, supporting visitors } \\
\text { 28. Friendly, polite with visitors }\end{array}$ \\
\hline
\end{tabular}

\subsection{Labor Situation of Community Ecotourism in Tuyen Quang Province}

\subsubsection{Brief introduction to Tuyen Quang province [5]}

Tuyen Quang province, the North borders Ha Giang province, the Northeast borders Cao Bang, the East borders Bac Can and Thai Nguyen provinces, the South borders Vinh Phuc, the Southwest borders Phu Tho, the West borders Yen Bai. Tuyen Quang is located in the center of Lo - Gam river basin. Tuyen Quang province includes 1 city and 6 districts with the economy: agro-forestry dominates and economic model: farm combined with agro-forestry.

3.2.2. Current situation of community ecotourism vocational training in Tuyen Quang province.In fact, the community ecotourism vocational training here does not have a strong own program, but it is part of general tourism vocational training, often spontaneous of local people.

\subsubsection{Current status of tourism activities in Tuyen Quang province}

Currently, Tuyen Quang tourism, especially community ecotourism does not have an official logo or slogan, communication is very limited, only at an average level, and at a poor level. However, in recent years, the tourism industry in Tuyen Quang province, including the contribution of community ecotourism, has achieved certain achievements.

The number of tourists to Tuyen Quang has increased sharply, from 603,000 visitors in 2011 to $1,309,000$ visitors in 2015, an average annual increase of $21.38 \%$ - a relatively rapid and steady increase over the years, with mainly domestic visitors with an average annual increase of $21.79 \%$, foreign visitors account for a small proportion and decrease over the years, most of them come from China and Korea. Revenue from tourism is 552,000 million VND in 2011, by 2015 reaching 1,135,000 million VND, an average increase of $19.74 \%$ per year..

Table 2. Current status of tourism development in Tuyen Quang province in 2011 - 2015(Unit: people)

(Source: self-built by author)

\begin{tabular}{|l|l|l|l|l|l|l|}
\hline Year & 2011 & 2012 & 2013 & 2014 & 2015 & Tốc độ (\%) \\
\hline Domestic & 592.000 & 718.000 & 849.990 & 1.009 .100 & 1.302 .700 & 121,79 \\
\hline Foreign & 11.000 & 12.000 & 10.410 & 5.900 & 6.300 & 86,99 \\
\hline Total & 603.000 & 730.000 & 860.400 & 1.015 .000 & 1.309 .000 & 121,38 \\
\hline Revenue (million dong) & 552.000 & 602.000 & 880.000 & 908.000 & 1.135 .000 & 119,74 \\
\hline
\end{tabular}

(Source: Department of Culture, Sports and Tourism of Tuyen Quang province) 
Particularly in 2016, the number of international tourists reached 10 million, an increase of more than 4.3 times compared to 2001; Domestic tourists reached 62 million people, an increase of 5.3 times compared to 2001; Direct contribution is estimated at $6.8 \%$ of GDP, both indirect and pervasive at $14 \%$ of GDP.

In 2018, tourism continued to flourish, gradually becoming an important economic sector of the province: attracting over 1.7 million tourists, reaching $102 \%$ of the plan, up $7.7 \%$ compared to 2017 ; social revenue from tourism reached 1,504 billion. A number of tourism development projects are being implemented in My Lam Mineral Spring Tourist Area, Na Hang - Lam Binh Tourist Area;

The master plan for the development of Tan Trao national tourism area to 2030 has been approved by the Prime Minister as an important premise for tourism development in the province. [(Source: Department of Culture, Sports and Tourism of Tuyen Quang province)

\section{(1) Number of employees of community ecotourism in Tuyen Quang province}

Nationwide, according to the report of the Ministry of Culture - Sports - Tourism, there are over 1.3 million tourism and related workers, accounting for about $2.5 \%$ of the total national workforce, of which about 420,000 workers directly work in tourism service establishments. Thus, there is a lot of human resources for tourism. In 2015, the demand for direct labor in the Tourism industry is estimated at 503,200 people and the average annual growth rate is $10.2 \%$. The number of trained workers needs to increase by about 19,000 people per year. This is an opportunity, but also a challenge when the quality of the labor force of the tourism industry has not really met the needs of the market.

The current status of tourism training is still limited in quantity, especially the quality has not met the social needs. In fact, many universities are very heavy in theory, separating the social needs between schools and businesses. Training should meet the needs of society, reduce the academic character. The demand for the quality of the human resources in the tourism industry is increasing, posing opportunities for learners and challenges for users.

High-quality tourism human resource is an extremely important factor to achieve the high competitiveness of the tourism destination in general and each business in particular, to the new requirements.

In Tuyen Quang province, the labor force from 15 years old: 485,504 people, of which the rate has been trained $20.4 \%$. Of which, 13,000 for tourism, 3,000 direct. Tourism workers are still unprofessional, weak in communication skills, spirit, and service attitude. Labor with foreign language skills to communicate with foreign tourists is very few. Therefore, Tuyen Quang province in the period 2016-2020 period of the People's Committee must strive for $100 \%$ of cadres, civil servants and public employees in the tourism industry to be fostered with state management knowledge on tourism, $60 \%$ of the tourism workers are directly fostered with professional knowledge.

The goal of the Tuyen Quang tourism industry, including community ecotourism, by 2020 is to welcome 2.2 million tourists, creating jobs for 16,000 tourism workers; tourist technical infrastructure is relatively synchronous in key tourist areas and spots of the province; By 2020, strive to have $100 \%$ of cadres, civil servants and public employees in the tourism industry fostering knowledge of state management in tourism; $60 \%$ of the tourism workers are directly fostered with professional knowledge.

\section{(2) Labor quality of community ecotourism in Tuyen Quang province}

Quality is measured by many component indicators: illiteracy rate, high school, junior high school, university, college, vocational school graduation rate on population size ...Tuyen Quang's tourism development faces many labor difficulties. The provincial tourism management apparatus at the Department of Culture, Sports and Tourism is both lacking and weak, making it difficult to advise leaders on the orientation of tourism planning and development.

The Department of Culture, Sports and Tourism of the Northwest and the recruitment agencies assessed that tourism management staff have not met the requirements, especially the district staff is both lacking and seriously weak. There are few people trained in tourism, so the formulation of development plans and plans is confusing, with weak language skills, no staff can transact or read documents in foreign languages. . In 2015, the province's literacy rate of the population aged 15 and over is the lowest in the country $(90 \% / 94.8 \%)$. 
In 2015, the province had 262 accommodation establishments (an increase of 125 accommodation establishments compared to 2011) and 06 tour operators. Meanwhile, the average occupancy rate is nearly $60 \%$. The service system is still sketchy. The highlight of community ecotourism is that homestays are also very few

In small hotels, motels, homestays, the service team is not professional, most of them are common workers, seasonal workers, so they are not professional. Many accommodation establishments, restaurants and services use receptionists, rooms, rooms, chefs ... with no or lack of experience in the field of tourism, no tourism specialized degree.

Current status of community ecotourism vocational training in Tuyen Quang Tourism vocational training in Tuyen Quang is getting more and more attention (see Table 4).

Table3. Vocational training activities in Tuyen Quang province in 2015

(Source: self-built by author)

\begin{tabular}{|l|l|l|l|l|l|}
\hline Field & $\begin{array}{l}\text { Funding } \\
\text { support (million } \\
\text { VND) }\end{array}$ & Number of class & $\begin{array}{l}\text { Number of } \\
\text { trainees }\end{array}$ & Đối tượng & \\
\hline $\begin{array}{l}\text { Agriculture, } \\
\begin{array}{l}\text { Forestry and } \\
\text { fishery }\end{array}\end{array}$ & 4.125 & 74 & 2.508 & $\begin{array}{l}\text { Enjoy } \\
\text { preferential } \\
\text { policies }\end{array}$ & 2.257 \\
\cline { 1 - 5 } Nonagricultural & & 32 & 1.103 & $\begin{array}{l}\text { Near-poor } \\
\text { households }\end{array}$ & 158 \\
\cline { 3 - 6 } & & 106 & 3.611 & Other & 1.196 \\
\hline
\end{tabular}

The number of employees who have linked and created jobs after vocational training is 2,632, accounting for $72.88 \%$. The network of vocational training institutions in Tuyen Quang province is interested and developed.

Table4. Network of vocational training institutions in Tuyen Quang province

\begin{tabular}{|l|l|l|l|l|l|l|}
\hline Total & University & $\begin{array}{l}\text { Vocational } \\
\text { college }\end{array}$ & Vocational & $\begin{array}{l}\text { Professional } \\
\text { high school }\end{array}$ & $\begin{array}{l}\text { The career center } \\
\text { has vocational } \\
\text { training activities }\end{array}$ & $\begin{array}{l}\text { Vocational } \\
\text { training } \\
\text { center }\end{array}$ \\
\hline 17 & 1 & 1 & 2 & 2 & 1 & 10 \\
\hline
\end{tabular}

(Source: self-built by author)

All 6 districts in the province have district vocational training centers, and the vocational training centers under the management of the district have been assigned the task of continuing education. Besides, the process of spontaneous vocational training in localities in the province; families and localities have been spontaneous vocational training but have had certain successes.

Table5. Vocational training levels for community ecotourism in Tuyen Quang

\begin{tabular}{|l|l|l|}
\hline Seq. & Vocational training system & Vocational training \\
\hline 1 & Elementary occupation & $\begin{array}{l}\text { Receptionist, housekeeping, waiter, } \\
\text { bartender. }\end{array}$ \\
\hline 2 & intermediate level & $\begin{array}{l}\text { Food processing techniques, } \\
\text { receptionist operations, restaurant }\end{array}$ \\
\hline 3 & College & Hotel management \\
\hline 4 & University & Travel service management \\
\hline
\end{tabular}

(Source: self-built by author)

Training institutions are oriented towards a priority model for practice, but lack of facilities for practice. The vocational skills of the trained workers do not meet the practical requirements of tourism business establishments. Learners are often trained in a variety of occupations, from receptionist, housekeeping, waiter, bartender ... but do not specialize in each profession. In addition, each school trains human resources for tourism according to its own curriculum, so it has a significant impact on the quality of output. Most graduate students lack the skills needed to be able to immediately access the assigned job position.

General assessment of tourism vocational training in Tuyen Quang 
Basically, the vocational training activities in Tuyen Quang have improved in recent years. That proves that the proper investment of the Party and State in the province's economic development has many implications. The indicators for the quality of education in the region are still low compared to the growing requirements of the country. Some policies have been issued, but tourism resources for policy implementation are inadequate.

Tuyen Quang has carried out the model of vocational training association, but it is still loosely with low efficiency. Entities participating in the association have not really agreed, even showed signs of obstructing each other's activities.

\section{SOLUTION Linking ACTORS In COMMUNity ECOTOURISM VOCATIONAL Training In TUYEN QUANG}

\subsection{The General Orientation with the Subjects Linking Vocational Training is to Ensure the} Same Activities in Harmonious Unity.

(1) Reaching consensus among actors in the perception of high-quality tourism human resources, in coordinating assignment in the preparation of necessary conditions, legal corridor in training and developing high-quality tourism human resources, in identifying vocational training motto.

(2) Perfecting strategies and strategies in link for training

Subjects share a common voice on the approach to international integration of training:Orientation of sub-sectors or fields in tourism research and training to deploy training of training levels corresponding to some fields:

\subsection{Proposing Solutions to Each Subject in Vocational Training in Tourism and Community Ecotourism}

\subsubsection{Proposing Solutions to State Management Agencies in Community Ecotourism Vocational} Training

(1) Determine the right and clear direction the needs of developing tourism human resources for each period. Strengthening capacity for policy making, establishing legal corridors and mechanisms for community ecotourism vocational training.

(2) Develop policies and mechanisms for coordination among actors to renew and strengthen the state management in building sustainable links between state management agencies, schools, houses and businesses in general tourism and community ecotourism vocational training.

(3) The State renews and strengthens the work of state management on building sustainable links between actors on 3 aspects: Orientation, encouragement and support.

\subsubsection{Proposing Solutions to Schools - Vocational Training Institutions}

(1) Improve the expertise and deepen development of the faculty through new training, retraining and fostering, gaining experience, ...

(2) Complete the curriculum framework with the orientation of approaching advanced training programs in the world combined with the development of various forms of training and retraining (joint training, postgraduate, short-term refresher classes,.).

(3) Increase the content of knowledge as practical behavioral skills for learners and strengthen cooperation and exchange with international projects in human resource development training.

(4) Increase investment in facilities and equipment for teaching and practice of students.

(5) Promote the active and active role of learners, under the leadership of teachers

\subsubsection{Proposing Solutions to Local People.}

Local people are the main target to be affected,at the same time playing a key role of local tourism development, playing a key role of local tourism development. Local people's support and participation is extremely important to the success of tourism development projects. In doing so, it is impossible not to increase people's awareness of economic benefits and cultural benefits 
Together with the tourism department, tourism businesses, local authorities and residential communities, build a standardized community tourism model in craft villages and trade streets.

If there are conditions for accommodation establishments (place to eat, live, play, ..); For tourism products and services, local families should actively become tourism establishments with the help of tourism businesses and the state, schools in the respective fields of activity.

\subsubsection{Proposing Solutions to Tourism Businesses}

(1) Must build a flexible salary and bonus mechanism to attract, retain and promote the role of high-quality human resources working in the businesses.

(2) Focusing on vocational training association in many modes. Businesses should support financial as well as facilities in the form of supporting scholarships for students, signing consultancy contracts, scientific research. Businesses can send experts, engineers, skilled workers to directly participate in teaching or practical instruction at the school.

(3) Having appropriate policies to actively welcome apprentices to internships and work, with priority given to ethnic minorities

\section{CONCLUSiON}

The Party and State always pay special attention to the socio-economic development of the mountainous provinces, including Tuyen Quang with specific policies, programs and actions.

However, to bring Tuyen Quang tourism to develop in accordance with the orientation of Resolution No. 08-NQ / TW dated January 16, 2017 of the Politburo, the province needs to synchronously solve the shortcomings and limitations in the actual operation process and implement integrated and synchronous solutions, enhancing the role of linking the four actors (the State, the school, local people and businesses) in Tuyen Quang tourism vocational training

\section{REFERENCES}

[1] OECD (2002), Deílnition and Selection of Competencies: Theoretical and Conceptual Foundation

[2] Luong Viet Thai (project leader), Nguyen Hong Thuan, Pham Thanh Tam ... (2011), Development of general education programs in the direction of developing learners' competencies,Scientific research topic, Code: B2008-37-52 TD, Hanoi.

[3] Ngo Trung Ha (2017), "Competency framework in training human resources for tourism", Journal of Science, Ho Chi Minh City University of Education, ISSN: 1859-3100 Volume 14, No. 11 (2017)

[4] wikipedia.org ttps://vi.

[5] www.ilo.org,www.itdr.org.vn.www.en.tnu.edu.vn,

\section{AUTHOR'S BIOGRAPHY}

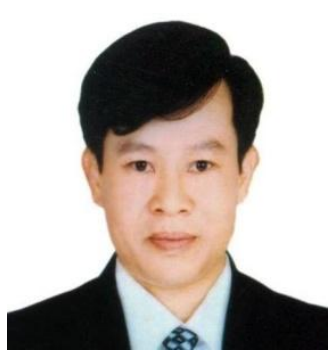

Le Ngoc Thong, PHD. Senior lecturer in Department of Political Theory, National Economics University, Vietnam.

Citation: Le Ngoc Thong. " Links between State, School and Businesses in Training Community Ecotourism at Tuyen Quang Province (Vietnam): Situation and Solutions" International Journal of Humanities Social Sciences and Education (IJHSSE), vol 8, no. 3, 2021, pp. 81-89. doi: https://doi.org/10.20431/2349-0381.0803008.

Copyright: () 2021 Authors. This is an open-access article distributed under the terms of the Creative Commons Attribution License, which permits unrestricted use, distribution, and reproduction in any medium, provided the original author and source are credited. 